\title{
Da atração por um enigma: os caminhos de Claude Lefort à obra \\ Maquiavel $^{1}$
}

\author{
Dario de Negreiros ${ }^{2}$
}

\begin{abstract}
Resumo: Neste artigo, esforçamo-nos para retraçar os caminhos que - ao longo das décadas de 1950 e 1960 - conduziram Claude Lefort à obra Maquiavel, para a qual viria a dedicar, posteriormente, seu mais longo estudo. De modo sumário, passamos por alguns momentos importantes de seu percurso como intelectual-militante e, com mais vagar, trataremos do modo como Lefort coloca em relação os pensamentos de Maquiavel e Marx. Trata-se, portanto, de analisar os deslocamentos lefortianos prévios à escrita de Le Travail de l'xuvre Machiavel (1972), percorrendo as sendas pelas quais gradualmente sua curiosidade se deslocaria do pensador prussiano ao florentino.
\end{abstract}

Palavras-chave: Lefort - Maquiavel - Marx - O trabalho da obra Maquiavel

\section{The attraction to an enigma: Claude Lefort's paths to Machiavelli}

\begin{abstract}
This book" - says Claude Lefort about his opus magnum, Le Travail de l'cuvre Machiavel (1972) - "was born from the attraction to an enigma, about which we would not be able to say all the motives". In this article, striving to retrace the paths that led Lefort to Machiavelli, we ask: if the manifest speech of the French philosopher is dedicated to the work of the Florentine secretary, how would this object be inserted in his hic et nunc, latent theme which motivated him to carry out his longest study? To do so, we must, at first, pass through some important moments in his journey as an intellectual militant. Finally, we will analyze the way Lefort puts the thoughts of Machiavelli and Marx in relation.
\end{abstract}

Keywords: Lefort - Machiavelli - Marx - Machiavelli in the making

\footnotetext{
${ }^{1}$ Este artigo é resultado de uma dissertação de mestrado apresentada ao Departamento de Filosofia da USP, orientada pela Profa. Dra. Marilena Chaui, e recebeu o apoio do CNPq durante o processo de sua escrita.

2 Doutorando em Filosofia pela Universidade de São Paulo.
} 
Há uma relação particular que a filosofia política mantém com a escrita. Quem a ela se dedica, adverte Lefort ${ }^{3}$, "não pode ceder inteiramente à ilusão de se desligar de seu tempo", como se seus escritos não tivessem destinatários contemporâneos reais ou pressupostos, como se não se inserisse e não interviesse em um debate mais ou menos importante para os acontecimentos de sua época.

Em uma palavra: todo e qualquer escrito que aceite o desafio do político direciona-se em alguma medida à sua época, mede suas letras a partir dos debates que lhe são coetâneos, insere-se nas disputas políticas presentes e, mesmo que não as tematize explicitamente, não pode deixar de expressá-las como palavra latente, fio invisível que guia e sustenta a costura de seu discurso manifesto. Eis o desafio inescapável: ao escrevermos sobre política, a alguém nos endereçamos com um propósito, inevitavelmente, propriamente político.

No presente artigo, esforçamo-nos para retraçar os caminhos que, ao longo das décadas de 1950 e 1960, conduziram Lefort ao pensamento maquiaveliano, ao qual viria a dedicar, posteriormente, seu opus magnum 5 . Para tanto, deveremos passar rapidamente por alguns momentos importantes de seu percurso como intelectual-militante e, com mais vagar, trataremos do modo como nosso autor coloca em relação os pensamentos de Maquiavel e Marx. Trata-se, neste artigo, portanto, de analisarmos os deslocamentos lefortianos prévios à escrita do TdoM, sendas pelas quais gradualmente sua curiosidade se deslocava do pensador prussiano ao florentino.

"Este livro" - eis a frase com a qual Lefort inauguraria sua mais importante obra "nasceu da atração por um enigma, sobre a qual nós não saberíamos dizer todos os motivos" ". Quais seriam, afinal, os motivos de sua atração pelo enigma Maquiavel?

\section{Maquiavel, o outro de Marx}

Quando indagado sobre seu interesse na obra do secretário florentino, Lefort afirma: "De certa forma, eu me voltei a Maquiavel como ao outro de Marx"7.

"Outro"; curiosa expressão, mas que nesta entrevista concedida em abril de 1978 parece ser utilizada em sua acepção mais corriqueira: enquanto o marxismo ignoraria o problema do político, uma vez que "pretende encontrar o fundamento da realidade social tão somente nas relações de produção", Maquiavel, ao contrário, teria feito do político o centro de sua reflexão. Um mês depois, em maio, Lefort não hesitaria em formular sua resposta nos mesmos termos ao Le Monde, desta vez ainda mais enfático, quando novamente indagado sobre os motivos de seu interesse em Maquiavel:

\footnotetext{
${ }^{3}$ Todos os trechos de obras não-lusófonas citadas neste trabalho constituem traduções livres.

${ }^{4}$ LEFORT, Écrire - à l'épreuve du politique, p. 11.

${ }^{5}$ Le Travail de l'cuvre Machiavel. Paris, Gallimard, 1972 (doravante TdoM).

${ }^{6}$ LEFORT, Le travail de l'auvre, Machiavel, p. 9.

${ }^{7}$ LEFORT, Le temps présent, p. 347.

${ }^{8}$ LEFORT, Le temps présent, p. 347.
} 
Maquiavel me atraiu por múltiplas razões. Mas há uma que é preciso mencionar antes de qualquer outra. Desde cedo me atentei a uma lacuna da problemática marxista: a lacuna do político. ${ }^{9}$

Perfeitamente simétrico, ainda que inverso, é o ponto de partida - adotado para em seguida melhor ser desconstruído - do texto "Maquiavel: a dimensão econômica do político":

Maquiavel - gostam de repetir - afirmou plenamente a autonomia do político: da reflexão política em relação à ética; dos fatos políticos em relação aos fatos da cultura e aos fatos econômicos. (...) Deveríamos, notadamente, reconhecer que Maquiavel deixa 'fora de sua investigação tudo o que constitui a vida social e econômica'. ${ }^{10}$

Perfaz-se, assim, a oposição: enquanto o marxismo autonomizaria o econômico e ignoraria os fatos do poder, Maquiavel autonomizaria o político e ignoraria os fatos da economia. Maquiavel, o outro de Marx: "outro", até aqui, não é outra coisa senão o anverso, o contrário, o oposto, imagem em negativo: a sombra do pensamento de um é o foco dos holofotes do outro. Tomemos o termo, pois, ao menos inicialmente, nesta acepção, vejamos até que ponto podemos sustentá-la e deixemos que nossa investigação nos conduza, se ela assim nos exigir, a eventuais complicações.

Da vulgata marxista, Lefort não precisou do encontro com Maquiavel para se manter afastado. A ideia de uma teleologia da história, bem como de uma possível determinação científica do fenômeno social - em resumo, "a versão mecanicista e determinista" marxismo -, desde cedo Lefort, contra certo marxismo mas ainda com Marx, recusaria:

eu jamais sustentei a concepção cientificista, economicista, segundo a qual Marx teria descoberto as leis que regem o funcionamento da sociedade e a evolução da humanidade. Meu temperamento intelectual, mas também o encontro com Merleau-Ponty, e graças a ele com a fenomenologia, quando eu ainda era muito jovem, me preservaram desta perversão. ${ }^{12}$

Se, portanto, Lefort não cansará de afirmar que "a noção de indeterminação da história sempre foi para [ele] essencial" ${ }^{\prime \prime}$, e se esta se deve antes a seu precoce encontro com Merleau-Ponty do que com Maquiavel, tampouco deixa de ser claro que a radicalidade da indeterminabilidade do poder e do saber que encontrará na letra maquiaveliana pode ser elencada como um dos elementos que motivaram sua atração, permitindo-o renovar sua munição contra a "perversão" de um marxismo mecanicista e determinista.

Até aqui, fogo amigo de um intelectual militante de Socialisme ou Barbarie, engajado na tarefa de alvejar a vulgata marxista para melhor defender Marx. Mas uma modulação

\footnotetext{
${ }^{9}$ LEFORT, Le temps présent, p. 359.

${ }^{10}$ LEFORT, As formas da história, p. 142.

${ }^{11}$ LELLOUCHE, L'invention du politique.

${ }^{12}$ LEFORT, Le temps présent, p. 359.

${ }^{13}$ LEFORT, Le temps présent, p. 842.
} 
fundamentalmente diferente aparecerá em sua fala quando começar a direcionar sua crítica ao modo de compreensão marxiana do estatuto do poder, da divisão social e, em consequência, do conceito de revolução. Agora, diz: "eram os princípios fundamentais da ação revolucionária (...) que eu queria colocar em questão. E, de saída, a própria imagem da Revolução"14.

Mais uma vez, não teria sido o secretário florentino, contudo, o pivô da separação. Indagado se seu "divórcio com Marx" ocorrera simultaneamente à sua descoberta de Maquiavel, Lefort responde negativamente: a ruptura se consuma, diz, em 1956, explicando: "é uma data precisa no meu itinerário"15. E acrescenta: "é um pouco mais cedo que eu começo a trabalhar sobre Maquiavel, nos anos 1954 e 1955" "16. A ruptura parece vir antes do olhar ao mundo do que do estudo de uma obra de pensamento: 1956, "data precisa", pois data de dois acontecimentos históricos fundamentais para o crescimento da perspectiva crítica à experiência soviética: o Relatório Khrushchov e a Revolução Húngara. Apenas neste momento, e tocado por estes dois eventos, afirma: "eu verdadeiramente compreendi o caráter totalitário do comunismo soviético" 17 .

Se a importância de Maquiavel é pela segunda vez menosprezada na resposta, é seguro que será a partir dele que Lefort irá assentar as bases de suas críticas e - não há dúvidas de que residem aqui outros motivos de sua atraşão. A quem estava às voltas com o modo como a divisão social, longe de desaparecer, tornara-se tão profunda quanto denegada no totalitarismo soviético, é evidente a valia de um pensamento no qual a divisão social deixa de ser divisão de fato, portanto contingencial e passível de ser suprimida, para se tornar divisão insuperável:

Para nossos leitores, que conheceram a empreitada extraordinária que, sob o nome de comunismo, se dá por fim a plena emancipação do povo, a lição de Maquiavel é plenamente confirmada pela história. Da destruição de uma classe dominante surgiu não uma sociedade homogênea, mas uma nova figura da divisão social. ${ }^{18}$

Duas são, precisemos, as novidades. Decerto, “o filósofo florentino tinha, bem antes de Marx, destacado a divisão de classes em todas as sociedades históricas, mas ele não a fazia derivar de um estado de fato", a saber, não a fazia derivar do "estado de desenvolvimento das forças produtivas e da divisão do trabalho" "19. Em adição, além de deixar de ser entendida como contingente, a divisão, em Maquiavel, é desdobrada em duas: constitutivamente dividida entre aqueles que desejam dominar e aqueles que desejam não ser dominados, a sociedade, não obstante esta cisão interna, forma ainda um conjunto social; este, por sua vez, é um dos termos de uma segunda divisão: a sociedade está insuperavelmente cindida do lugar do poder.

A questão de Maquiavel, e que Lefort traz para si, pode então ser assim formulada: "como conceber um pensamento que permita alcançar a realidade social como estando

\footnotetext{
${ }^{14}$ Entrevista concedida em 1975, disponível em LEFORT, Le temps présent. A presente citação faz referência, precisamente, à p. 236.

15 LELLOUCHE, L'invention du politique.

${ }^{16}$ Idem. Seria no Brasil, enquanto lecionava filosofia como assistente do professor João Cruz Costa, que Lefort viria a iniciar seus estudos mais sistemáticos sobre Maquiavel: "ele levou seu Maquiavel para o Brasil, onde este foi o tema de diversos cursos na Universidade de São Paulo (1953-54)". (BATAILLON, "Claude Lefort, the Practice and Thought of Disincorporation". In: PLOT, (org.), Claude Lefort: thinker of the Political, p. 94).

${ }^{17}$ Idem.

${ }^{18}$ LEFORT, Écrire - à l'éprewve du politique, p. 174.

${ }^{19}$ LEFORT, Le temps présent, p. 360.
} 
simultaneamente unificada por uma perspectiva e rasgada pelo enfrentamento entre grupos ou classes?" ${ }^{20}$. A tentativa de compreensão desta contradição virá pela investigação desta dupla divisão que permite o surgimento de uma paradoxal unidade não una, uma sociedade que, embora cindida, não deixa de ser uma sociedade:

Lefort percebe ter em mãos, assim, um pensamento capaz de nos desiludir duas vezes: por um lado, "Maquiavel dissipava a ilusão de uma sociedade que se ordenaria sem divisão" 21 , de uma sociedade una, que por não estar internamente cindida entre Grandes e Povo eliminou de si a figura do conflito. Em uma palavra: desfaz-se a ilusão da boa sociedade. Por outro lado, não sendo possível que poder e conjunto social formem um só corpo, o florentino "dissipava ao mesmo tempo a ilusão de que poderia haver um bom poder, seja acima das classes, árbitro dos conflitos, seja confundido com o povo inteiro" ${ }^{22}$. Não há poder que, ao ser exercido, não seja mais ou menos violento, mais ou menos opressor e mais ou menos mistificador:

(...) o poder, mesmo o melhor, será sempre o poder. Ele abordará sempre a sociedade (...) no interior (...) do quadro de representações que lhe impõe (...) sua distância em relação à vida das pessoas na sociedade. (...) aos meus olhos, o poder (...) será sempre, no melhor dos casos, mais ou menos malvado [a demi mawvais 7.23

Se se entende, portanto, que o ato revolucionário é aquele que funda uma sociedade em cujo interior não há mais separação entre dominantes e dominados e na qual o lugar do poder se confunde com o lugar do conjunto social, ou seja, uma sociedade capaz de abolir esta dupla divisão, eliminar o conflito e libertar definitivamente o povo tanto da opressão do Poder quanto da opressão dos Grandes, então esta imagem de Revolução Lefort não mais poderá sustentar:

a ideia da revolução como acontecimento absoluto, fundação de um mundo no qual os homens dominariam inteiramente as instituições, se colocariam de acordo no conjunto de suas atividades e de seus fins, (...) esta ideia está secretamente ligada com a representação totalitária. ${ }^{24}$

Mas há também, lembremos, revolucionários mais bem avisados, aqueles que conhecem bem a falácia das ideias de unidade e homogeneidade do social e que sonham com a sociedade da plena abertura ao novo, da radical legitimidade da diferença e do permanente reconhecimento da produção de multiplicidades próprias à potência disruptiva da vida. Ora, esta ausência completa de óbices à diferenciação não pode, decerto, conviver com uma concepção que sustenta as inevitabilidades do caráter opressivo do poder e da insaciável dominação dos Grandes. Sejamos, pois, rigorosos com nosso próprio autor e destaquemos que muito embora no trecho acima, escrito em 1976, ele associe sem ressalvas a imagem da

\footnotetext{
${ }^{20}$ POLTIER, Claude Lefort: la découverte du politique, p. 32.

${ }^{21}$ LEFORT, Le temps présent, p. 360.

22 Idem.

${ }^{23}$ LEFORT, Le temps présent, p. 355.

${ }^{24}$ LEFORT, Le temps présent, p. 268.
} 
boa sociedade e do bom poder à experiência totalitária, sua descrença nestas ideias vai ainda mais longe. O que fica claro nesta entrevista concedida duas décadas depois, em 1996:

Na minha juventude eu encontrava em Marx - era uma utopia, eu estou de acordo - o esboço um pouco maluco de uma sociedade em que cada um poderia, ao seu tempo, exercer a mesma função, onde não haveria clivagens decisivas devidas à divisão do trabalho, em que se daria espaço de direito à espontaneidade. Assim, a ilusão a qual eu cedi foi a de uma sociedade completamente efervescente. Outra coisa é a imagem de uma coletividade que, de algum modo, se dobra sobre si mesma, uma sociedade totalitária, na qual os indivíduos estão sob a autoridade de um senhor. ${ }^{25}$

Façamos, enfim, o recenseamento dos deslocamentos operados: (i). de um pensamento que deixa o político à sombra àquele cujo foco é o poder; (ii). da concepção determinista da história ao pensamento da indeterminação radical; (iii). da contingência de uma divisão de fato à insuperabilidade de uma dupla divisão produtora de uma paradoxal unidade cindida; (iv). da ação revolucionária com vistas à fundação da boa sociedade à inevitabilidade da opressão do Poder e dos Grandes.

Não por acaso, dois anos após a "ruptura de 1956" tornar-se-ia impossível para Lefort permanecer no grupo Socialisme ou Barbarie. Pois, de fato - e ainda que ao observarmos de nossos dias possa nos parecer evidente a ingenuidade do projeto - trata-se não apenas de uma revista acadêmica de alto nível, mas de um grupo que "se acreditava o embrião de uma organização revolucionária" ${ }^{\prime 26}$.

Haveria muito a ser dito sobre a ruptura de Lefort com o grupo que formava Socialisme on Barbarie. Mas, para nossos propósitos, basta destacar que este estudioso de Maquiavel já não mais acreditava em uma perspectiva dirigista, "organizacionalista" 27 , de um pequeno apanhado de intelectuais cuja identidade maior consistia no devaneio comum de encarnar o polo diretor do que deveria vir a ser, um dia, uma espécie de vanguarda da classe trabalhadora mundial em sua marcha revolucionária.

Sonhos que se tornariam ainda mais fortes em 1958, com o que Lefort chama de "golpe de Estado a frio" 28 de Charles De Gaulle, momento no qual os membros do grupo pensando estar diante de uma "virada histórica" que criara "um vazio político sem precedentes" ${ }^{29}$ na França - "acreditaram ter chegado a hora de construir a organização com a qual sonhavam" ${ }^{30}$. A permanência de Lefort se tornaria, então, insustentável. Assim, diz nosso autor, "na ausência de um movimento social do qual eu pudesse participar, convencime da necessidade e da legitimidade de um trabalho teórico". ${ }^{31}$ Neste mesmo ano de 1958, após gestar por mais de quatro anos as suas leituras de Maquiavel nas salas de aula das

\footnotetext{
${ }^{25}$ LEFORT, Le temps présent, p. 845.

${ }^{26}$ LEFORT, Le temps présent, p. 232.

${ }^{27} \mathrm{Idem}$.

${ }^{28}$ LEFORT, Le temps présent, p. 233.

${ }^{29}$ Idem.

${ }^{30}$ Idem.

${ }^{31}$ LEFORT, Le temps présent, p. 345.
} 
universidades de São Paulo e de Caen, Lefort leva um projeto de doutorado ao seu orientador, Raymond Aron.

\section{Habitados por um mesmo}

Em um colóquio ocorrido na cidade de Toronto, em 1974, Lefort se dedicará a desmontar a leitura que faz de Maquiavel um pensador desinteressado pelos aspectos econômicos do social e do político:

talvez nós nos decepcionemos porque não sabemos reconhecer na obra os momentos em que a análise política implica uma visão econômica. Estamos decepcionados, talvez, porque permanecemos prisioneiros de uma representação sumária tanto dos fatos econômicos quanto dos fatos politicos. ${ }^{32}$

Eis um momento em que Lefort fala de Maquiavel como bem poderia estar falando de si mesmo. Trata-se sobretudo, de inserir os pensamentos maquiaveliano e lefortiano no interior de uma mesma tradição: a tradição da filosofia política. Se quisermos, diz Lefort, definir a especificidade da filosofia política, "só podemos fazê-lo opondo-a ao espírito das ciências sociais ou das ciências humanas em geral" ${ }^{33}$. Afinal, alguém que advoga pela radical indeterminação dos fenômenos sociais não poderá enxergar em expressões como "ciências sociais" ou "ciências humanas" outra coisa senão uma contradição em termos: a tentativa de aplicação de métodos de redução científica àquilo que se define, justamente, por ser avesso à objetividade da ciência.

"Filosofia política", dirá Lefort, não como quem dá destaque à limitação inevitavelmente posta pela adjetivação, mas, ao contrário, como forma de ressaltar a abrangência imposta pelo substantivo. Pois não se trata de estabelecer distinções e erigir fronteiras entre diferentes tipos de filosofia - como um biólogo que, para delimitar sua diferença no interior do vasto campo da biologia, "se situa no quadro da biologia molecular, por exemplo" 34 . Ao contrário, trata-se de fazer o movimento oposto - remetendo a política à filosofia e não esta àquela - de modo a reivindicar ao pensamento sobre o político o quadro mais amplo da investigação filosófica, a saber: "uma interrogação do tempo no qual se vive" 35 . "O filósofo", entende nosso autor:

não pode se satisfazer com a separação estabelecida, de um ponto de vista científico, entre a política (entendida como o conjunto das atividades e das relações tocantes ao exercício do poder) e, de outra parte, a economia, o direito, os costumes etc. (...) Eu não quero dizer que toda a vida social é determinada pelo modo de definição e de representação do poder. (...) Eu quero somente colocar em evidência a ideia de "forma de sociedade" (...). ${ }^{36}$

\footnotetext{
${ }^{32}$ Grifos nossos. LEFORT, As formas da história, p. 144.

${ }^{33}$ LEFORT, Le temps présent, p. 601.

${ }^{34}$ LEFORT, Le temps présent, p. 600.

${ }^{35}$ LEFORT, Le temps présent, p. 601.

${ }^{36}$ LEFORT, Le temps présent, p. 602.
} 
E com a ideia de forma de sociedade retornamos, enfim, a Maquiavel. Pois, como explica Lefort, não pode haver autonomia do político - ou tampouco abandono do econômico àquele que se põe a pensar as formas do social. Resposta necessária, mas que, convenhamos, não é suficiente: afinal, nada nos impede de colocar a questão essencial: qual é, então, o ponto de Arquimedes apoiado no qual o florentino pode girar o seu mundo? A resposta já nos é conhecida: "a forma das relações sociais", Maquiavel "coloca através da divisão grandepovo"37.

Ao tocar este elemento nuclear, Lefort, longe de temer o anacronismo, faz questão de estabelecer uma relação de plena comutabilidade - algo que, por sinal, permanecerá ao longo de todo o TdoM - entre o que aparece no pensador renascentista como a divisão da Cidade entre o desejo do povo e o desejo dos grandes e um termo muito mais contemporâneo, que sabemos bem a quem devemos tributar. "Todo mundo sabe", relembra Lefort, "que Maquiavel concebe o poder em relação com a luta de classes" ${ }^{38}$.

"Maquiavel, o outro de Marx": eis que, enfim, começamos a chegar às complicações que trarão a esta expressão um outro significado. Procedamos então à análise de um texto publicado em 1960 na Cabiers internationaux de sociologie, no qual Lefort se propõe a confrontar as obras de Marx e Maquiavel. Confrontação cuja inspiração, logo de saída, nosso autor deixa claro se dever antes à percepção de um mesmo do que à de um outro:

A ideia de confrontar a obra de Maquiavel com a de Marx é sugerida pela observação segundo a qual tanto uma como a outra são habitadas por uma mesma paixão realista. ${ }^{39}$

Do outro entendido como oposto, contrário, inverso, passamos a um outro que, sem deixar de sê-lo, pode bem ser habitado por um mesmo.

\section{Por uma paixão realista}

Realismo: a aparição deste termo na pena de Lefort desconcerta e parece até mesmo emudecer os comentadores. Mas o que aqui poderia querer dizer realismo? Ou, para retomar a pergunta posta por Lefort, o que é o realismo em política? Procuremos seguir, inicialmente, a argumentação do autor. Logo de saída, a respeito da pergunta "que é o real?", uma afirmação grandiloquente:

É por ter enfrentado esta questão, sem se deixar inteiramente desviar pelo objeto de suas preferências, que uma teoria política, por mais ligada que seja a uma prática, pôde adquirir um alcance universal (..... ${ }^{40}$

Não haveria, para Lefort, pensamento político que transcenda os interesses específicos de sua época e de seu contexto social e histórico a não ser estes que, ousadamente, põem-se a enfrentar o enigma do real. São escritores que querem "descobrir os motivos em

\footnotetext{
${ }^{37}$ LEFORT, As formas da história, p. 144.

${ }^{38}$ LEFORT, As formas da bistória, p. 142. Grifo nosso.

${ }^{39}$ Grifo nosso.

${ }^{40}$ LEFORT, As formas da história, p. 183.
} 
virtude dos quais agem os indivíduos ou os grupos, assim como as causas que explicam o devir das sociedades" ${ }^{41}$. E, mais fundamentalmente: são escritores aos quais recorremos, admitamo-lo, não pela mera curiosidade erudita sobre as sociedades em que viviam, mas com alguma esperança de que suas leituras possam de algum modo transcender a problemática de seu tempo e nos ajudar a lançar luz à nossa própria época e aos nossos problemas. Do que decorre a pergunta:

O que é que, na obra de caráter político, a despeito do fato de que nasce nas fronteiras de uma sociedade e a aborda dentro dos traços particulares que lhe compõe um determinado estado da produção, das instituições e da cultura, desbrava uma via de acesso à realidade? ${ }^{42}$

Mas, notemos, há algo mais nesta discussão do que apenas o estatuto do realismo. Há o real, com efeito, mas há também um esforço de conquista; há uma via de acesso à realidade, mas há também alguém que a quer desbravar; há motivos e causas que explicariam indivíduos e sociedades, mas há antes aqueles que o supõem e que ousam tentar descobri-los.

Lefort costuma ser cirúrgico na escolha de seus termos - motivo pelo qual não poderíamos deixar o pequeno elefante do realismo passar pela sala sem ser nomeado. Mas igualmente não podemos esquecer do termo que o acompanha: o mesmo que habita Maquiavel e Marx é, antes de tudo, uma paixão. Habitados por uma mesma paixão realista:

Com este termo queremos, primeiramente, designar segundo o uso corrente o desejo ${ }^{43}$ de um modo de ação que responde a móveis e se subordina a fins cuja observação mostra serem efetivamente os móveis e os fins de uma humanidade empírica. ${ }^{44}$

Ouriçados que ficamos ao lermos termos que nos remetem ao domínio da objetividade - realismo, observação, efetividade, empiria - quase não nos damos conta de que todos eles estão a serviço da qualificação de um substantivo primeiro, radicalmente subjetivo: o desejo. Há, pois, um desejo fundamental. Mas, e agora carregando as tintas no termo que a ele se opõe, há também:

um sistema de realidade para além das quais o arbitrário do desejo, mesmo que ainda se regule em função de certas propriedades do objeto, não deixa de condenar o sujeito, irremediavelmente, a perder o controle de suas operações. ${ }^{45}$

Trata-se, portanto, da tentativa de examinar com lupa "as condições de fato" ${ }^{46}$, mas tendo como lente de aumento a "vontade de reconhecer nelas a origem de uma necessidade

\footnotetext{
${ }^{41}$ LEFORT, As formas da história, p. 185.

${ }^{42}$ LEFORT, As formas da história, p. 186.

${ }^{43}$ Grifo nosso.

${ }^{44}$ LEFORT, As formas da bistória, p. 187.

${ }^{45}$ LEFORT, As formas da bistória, p. 187.

${ }^{46}$ Idem.
} 
prática" "; trata-se bem de investigar a "realidade empírica, tal como a compõe a história dos homens" ${ }^{48}$, mas somente para, por meio desta investigação, chegar à descoberta, no interior desta realidade, daquilo que seria "o fundamento da ação adequada" ${ }^{49}$. É este, enfim, o mesmo que habita as obras de Maquiavel e Marx, o mesmo enigma de uma paixão realista:

Ambos partem da certeza de que o real é o que é e que, de uma certa maneira, não há nada a mudar nele, mas daí deduzem, todavia, uma tarefa prática: paradoxo deliberadamente enfrentado e aparentemente resolvido por meio do pensamento segundo o qual esta tarefa se acha inscrita na realidade empírica. ${ }^{50}$

Para melhor compreendermos esta aparente resolução do paradoxo, passemos rapidamente pela leitura lefortiana de um intérprete que a desenvolve.

Não há caminho mais simples e mais esclarecedor para compreendermos as peculiaridades do modo pelo qual Lefort confronta os pensamentos de Marx e Maquiavel do que, de saída, passarmos pela sua leitura sobre as características que esta mesma confrontação adquire sob outra pena: a de Antonio Gramsci. Não há melhor caminho, entenda-se, pois nenhum outro poderia deixar tão claro aquilo que Lefort não pretende fazer.

Isto de modo algum significa que nosso autor não reconheça os méritos da análise do marxista italiano. Gramsci, diz Lefort, bem compreendeu que a obra, ao mesmo tempo que constitui a "expressão da experiência histórica de uma classe" 51 , está não obstante para além de suas determinações históricas, que ela possui a inesperada capacidade de se projetar para outros tempos e espaços, que ela lança aos leitores presentes e futuros uma espécie de chamado a ser decifrado, que ela nos convoca, enfim, a "uma atitude teórica e um partido prático, que anunciam o encontro necessário de nosso pensamento com o seu" ${ }^{2}$. É deste modo, pois, que a obra política "desbrava uma via de acesso à realidade" ${ }^{53}$ e, desta percepção, Lefort e Gramsci compartilham plenamente. Esgotam-se aqui, contudo, as concordâncias. Se da obra depreendem-se um chamado a ser decifrado, uma atitude teórica e um partido prático, não restam dúvidas de que - ao menos na leitura de Lefort - os chamamentos que estes intérpretes decifram dissonam, que eles não adotam, no trabalho teórico, a mesma atitude, e que estão longe, na prática, de pertencer ao mesmo partido.

Não se trata, destaquemos, de avaliar aqui a justeza da crítica de Lefort à leitura gramscian $a^{54}$. Para os propósitos restritos deste artigo, interessa apenas observar que a análise

\footnotetext{
${ }^{47} \mathrm{Idem}$.

${ }^{48}$ Idem.

${ }^{49}$ Idem.

${ }^{50}$ Idem.

${ }^{51}$ CHAUI, "O pensamento da obra de pensamento", p. 25.

${ }^{52}$ LEFORT, As formas da história, p.186.

${ }^{53}$ Idem.

${ }^{54}$ Para Juarez Guimarães, o capítulo dedicado a Gramsci pelo filósofo francês em sua grande obra "é certamente uma das peças mais duras e fechadas à abertura de sentidos deste grande leitor que é Lefort" (GUIMARÃES, “A Revolução democrática e o momento Lefortiano da democracia brasileira”, pp. 133-134). De fato, se tal como Guimarães acompanharmos a generosa interpretação da letra gramsciana empreendida por Benedetto
} 
da crítica lefortiana ao marxista sardo constitui uma estratégia privilegiada de apreensão do modo como o próprio Lefort dispõe em relação os pensamentos de Marx e Maquiavel. Vejamos.

Ao levarmos em conta o apelo revolucionário marxista, como podemos considerar que a obra maquiaveliana mantenha com Marx outra relação senão a da mais bem acabada oposição? Afinal, se Maquiavel, como muitos interpretam, endereça sua palavra aos defensores da tirania, e se tanto se esmera em lhes dar instruções detalhadas com vistas à conservação do poder, como comparar o seu apelo àquele que, ao contrário, convoca o destinatário de sua mensagem à destituição do poder estabelecido? É precisamente a insuficiência da leitura que faz do Príncipe uma obra dedicada à conservação do poder tirânico que Gramsci, já de saída, irá demonstrar.

Que Maquiavel tenha exposto os termos de uma política tirânica, tenha envidado grandes esforços para descrever seu modo de funcionamento, tenha insistido na necessidade de avaliação dos fenômenos políticos em termos de relação de força, que ele tenha, enfim, construído algo que, com Gramsci, poderíamos chamar de um ensinamento de realismo político, nada disso é suficiente para concluirmos que seriam os interessados na manutenção do poder estabelecido que ocupariam o lugar de destinatário de sua mensagem. Aliás, poderíamos, muito antes, deduzir o contrário: pois toda opressão que se preza não abre mão da dissimulação, da mistificação, de esconder-se por detrás da máscara do interesse coletivo. E, se assim o é, quais benefícios poderia ter a revelação do rosto da tirania para aqueles que não só conhecem bem o que há por trás da máscara como, e principalmente, dependem dela? Deste modo, se o Príncipe:

atrai a atenção sobre a natureza do poder e revela que é uma criação humana saída das condições permanentes de luta social, é que se dirige àqueles que o poder cega e que não compreenderam ainda que está a seu alcance logo que sejam os mais fortes e qual o preço de sua conquista. ${ }^{55}$

"Por conseguinte", interpreta Gramsci, se os que estão no poder já sabem o que o Príncipe tem para dizer, então "quem 'não sabe? A classe revolucionária de seu tempo, o 'povo' e a 'nação' italiana, a democracia cidadã" ${ }^{56}$. Chega a carta maquiaveliana ao seu destinatário: a burguesia florentina em ascensão, embora ainda não o saiba e não tenha conseguido dar a si mesma o líder do qual necessita, embora continue colocando em seus próprios olhos a venda do moralismo cristão, é, neste instante, a classe portadora da tarefa histórica. Se se dirige a um príncipe, "Maquiavel trata de como deve ser o Príncipe que queira conduzir um povo à fundação de um novo Estado" 57 . Dirige-se, então, não a qualquer príncipe, mas a um novo príncipe, il principe nuovo, capaz de, em sua vontade, expressar a vontade de um povo. Se este homem ainda não existe, cumpre então o papel de um mito capaz de dar "uma forma mais concreta às paixões políticas" 58 , uma figuração que irá corporificar e representar "de forma plástica e 'antropomórfica' o símbolo da vontade

Fontana, encontraremos entre as empreitadas de Lefort e Gramsci convergências significativas, desaguando ambas no esforço comum de promover o "retorno do marxismo à cultura do republicanismo democrático" (GUIMARÃES, “A Revolução democrática e o momento Lefortiano da democracia brasileira”, p. 135).

${ }^{55}$ LEFORT, As formas da história, p. 192.

${ }^{56}$ GRAMSCI, Notas sobre Maquiavelo, sobre la política y sobre el Estado moderno, p. 17.

${ }^{57}$ GRAMSCI, Notas sobre Maquiavelo, sobre la política y sobre el Estado moderno, p. 10.

${ }^{58}$ GRAMSCI, Notas sobre Maquiavelo, sobre la política y sobre el Estado moderno, p. 9. 
coletiva" 59 . Pode bem ser uma fantasia, mal não faz, uma vez que se trata de uma "fantasia concreta que atua sobre um povo disperso e pulverizado para suscitar e organizar sua vontade coletiva" ${ }^{60}$. Longe de servir aos interesses da classe dominante, e de modo análogo ao apelo marxista, o Príncipe maquiaveliano possui, na lente gramsciana, "uma função revolucionária por sua simples intenção: interpela homens que, mistificados, não têm interesse na mistificação"

Mas notemos, sobretudo, o modus operandi desta revolução: a classe revolucionária mistificada, dispersa e pulverizada - é incapaz de advir por si à organização de sua vontade coletiva e deve por isso, interpreta Lefort, "aceitar a mediação do príncipe para aceder à sua própria unidade" ${ }^{2}$. Como dirá Gramsci:

Pode-se considerar que Maquiavel quer persuadir estas forças da necessidade de ter um 'chefe' que saiba o que quer e como obter o que quer, e de aceitálo com entusiasmo, mesmo quando suas ações possam estar ou parecer em contradição com a ideologia difundida na época, a religião. ${ }^{63}$

Ora, a analogia que o intérprete tem em vista - a organização que em sua época deverá desempenhar o papel principesco, bem como a classe que deverá "aceitá-lo com entusiasmo" - não só parece evidente a Lefort, como também lhe parece clara a sua finalidade fundamentalmente defensiva:

Tanto o jacobinismo (...) quanto o bolchevismo (...) comporão as encarnações modernas do Príncipe: figuras em que o povo decifrará os traços de sua própria história, pessoas atuantes às quais dará, por sua fé, o poder de transformar o mundo. ${ }^{64}$

É este, na leitura lefortiana, o sentido do Príncipe gramsciano: discurso-apelo direcionado à burguesia florentina - massa portadora da tarefa histórica, que deve aceitar a necessidade da mediação do Príncipe para que consiga "aceder à sua própria unidade" 65 -, a obra de Maquiavel prefigura o discurso-apelo de Marx, que colocaria ao proletariado a necessidade de aceitação da mediação do Partido Comunista. E, se é assim, quando questionamos a verticalidade da estrutura hierárquica do partido e sua pertinência para a construção de uma sociedade sem classes, fazemo-lo tão somente porque, ingênuos, "não soubemos reconhecer que esta instituição ocupa na sociedade moderna a função principesca outrora definida por Maquiavel" "66 . Ao refletirmos sobre o dilema comunista com a ajuda do secretário florentino, "persuadir-nos-emos de que o Partido não pode ser diferente do que é" ${ }^{67}$. E é este, para

\footnotetext{
59 Idem.

${ }^{60}$ GRAMSCI, Notas sobre Maquiavelo, sobre la politica y sobre el Estado moderno, p. 10.

${ }^{61}$ LEFORT, As formas da bistória p. 192.

${ }^{62}$ LEFORT, As formas da história p. 193.

${ }^{63}$ GRAMSCI, Notas sobre Maquiavelo, sobre la politica y sobre el Estado moderno, p. 18.

${ }^{64}$ LEFORT, As formas da história, p. 194.

${ }^{65}$ LEFORT, As formas da bistória, p. 193.

${ }^{66}$ LEFORT, As formas da história, p. 194.

${ }^{67}$ Idem.
} 
Lefort, o sentido maior da empreitada gramsciana: por um lado, quer assegurar as massas da pertinência de colocar seus destinos nas mãos de um chefe; por outro,

quer trazer aos chefes a certeza de que estão no bom caminho quando subordinam todas as suas preocupações à conquista do poder e que, seguindo a razão aparentemente abstrata que governa a política, fazem-se de agentes da razão histórica. ${ }^{68}$

Não podemos deixar que, no campo do saber, haja lugar para a incerteza, assim como não podemos arriscar que, no campo da ação, faça-se espaço para a indeterminação. O enigma de uma paixão realista, tal como queríamos demonstrar, resolver-se-ia na proposição de que a tarefa de transformação da realidade se acha inscrita na própria realidade: política e realidade se juntam, enfim, porque a realidade é política. Quer seja em Marx, como uma tarefa "pouco a pouco formada no curso de uma história cumulativa até a etapa em que sua definição se torna evidente"69, quer seja em Maquiavel, como uma tarefa "sempre presente e sempre exposta ao acaso da aventura social em uma história repetitiva" ", trata-se de afirmar que realidade é práxis, ou seja, "que o presente é apreendido como aquilo que adveio graças à ação dos homens e faz apelo a uma tarefa" 71 .

Assim, dirá Lefort, sob a pena gramsciana todos os conflitos só existem para serem, em seguida, a-problematicamente solucionados: na massa revolucionária (burguesia florentina ou proletariado), resolve-se o conflito entre sua mistificação e sua tarefa histórica, graças à mediação do Príncipe ou do Partido; também se soluciona o conflito no interior das totalidades classe-instância (Burguesia-Príncipe ou Proletariado-Partido), graças às mediações dos discursos-apelo das obras (Príncipe e Manifesto Comunista); o realismo político do Príncipe-Partido e o realismo popular das massas se unem felizes na ação revolucionária; enfim, resolve-se o conflito entre as obras de Maquiavel e Marx graças à mediação, é claro, do próprio Gramsci.

Eis, acusa Lefort, a posição a que se arroga o pensador sardo: figura da onisciência que sobrevoa todos os tempos e obras, que é capaz de ocupar todos os lugares - de Maquiavel e de Marx, da burguesia florentina e do Príncipe, do proletariado e do partido, da teoria e da prática, da paixão e do realismo, da arbitrariedade do desejo e da imutabilidade da realidade, ambas resumidas na práxis revolucionária -, figura do autor-ator, que age porque sabe e sabe porque age ${ }^{72}$.

\footnotetext{
${ }^{68}$ LEFORT, As formas da bistória, p.196.

${ }^{69}$ Idem.

${ }^{70} \mathrm{Idem}$.

${ }^{71}$ LEFORT, As formas da bistória, p.195.

${ }^{72} \mathrm{Na}$ leitura da letra gramsciana empreendida por Fontana, ao contrário, "o partido não possui um conhecimento a cujas "verdades' seus seguidores e membros devem se submeter" (FONTANA, Hegemony and power, p. 15)2. Isto porque, como deixariam claro os escritos do pensador sardo, tal conhecimento "deve agora ser compreendido como sendo sempre interno ao povo, pois o filósofo democrático (o professor) é ele mesmo o produto do povo que ele pretende educar". Assim, quando lemos que Maquiavel quer ensinar ao povo o novo conhecimento político", seria crucial não nos esquecermos da noção gramsciana de ensino, para a qual “todo professor é também um estudante, e todo estudante é também um professor”. Ao que Fontana conclui: "É neste contexto" - radicalmente distinto, diga-se, daquele pressuposto pela crítica lefortiana - "que a discussão gramsciana do partido como o príncipe moderno deve ser conduzida" (FONTANA, Hegemony and power, p. 151).
} 


\section{Da exclamação à interrogação}

Quando perguntado se "existe uma possibilidade de oposição entre a bagunça endêmica na sociedade e a vontade de racionalização do poder ou dos contra-poderes?", Lefort responde antes ser possível "denunciar a bagunça, tentar agir (...) para que aqueles que dela são vítimas descubram o seu poder de transformar as condições que acreditam fatais". ${ }^{73}$

Observemos a cautela com que o filósofo constrói a frase, procurando deixar claro que não lhe cabe a tarefa de transformação da realidade: são antes as próprias "vítimas da bagunça" que detêm este poder. Cabe-lhe, assevera, denunciar a bagunça, ajudando-as a descobrir o poder que possuem e a tomar para si as rédeas da situação. Indicação de rumo que nos é preciosa para compreendermos, finalmente, o que Lefort entende pelo realismo de Maquiavel e Marx.

A vontade com a qual estes dois pensadores tentam se apropriar, em um pensamento posto à prova da ação, de toda a "extensão da história humana" "ao real sua verdadeira identidade" 75 (idem), se no frigir dos ovos não chega a entregar o que prometeu, tampouco deixa de apontar a quem se dedica à filosofia política uma via possível:

A vontade de preparar uma tal restituição, em pensamento e em ato, engendra tanto na obra de Maquiavel como na de Marx um procedimento crítico (...). Mesma ruptura com a tradição cultural de seu tempo (...); mesma recusa em substituir à ordem das paixões ou dos interesses uma essência do homem racional, fundamento do bom regime; mesma acusação lançada contra um humanismo moral que, sob a cobertura de um apego a valores abstratos, deixa livre o terreno ao exercício desordenado da violência (......$^{76}$

Ruptura, recusa, acusação: as palavras em destaque deixam claro que é no procedimento crítico que Lefort identifica os dividendos das paixões realistas. Podemos tomar para nós este realismo, portanto, desde que observemos que "a conquista do real se efetua na crítica

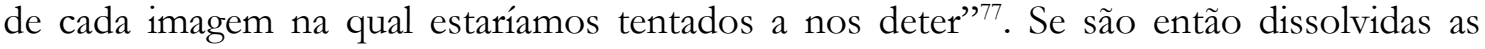
imagens que, ainda que imaginariamente, nos ofereciam respostas às nossas questões e apaziguavam nossos espíritos, procuremos não nos assustar com esta multiplicação dos pontos de interrogação: afinal, o "realismo não consiste precisamente em definir os termos de uma situação, em dispô-los em forma de questão?"

Retomando a oposição diametral estabelecida por Lefort entre sua leitura e a de Gramsci, diríamos, se tivéssemos de resumir nossas conclusões em uma frase: para Gramsci, mais próximo de Marx do que de Maquiavel, as obras destes autores são marcadas por um apelo exclamativo, possuem a forma de manifestos explicativos e nos asseguram, demonstrando a unidade entre pensamento e ação, de que seguimos o bom caminho; para Lefort, mais próximo de Maquiavel do que de Marx, estas obras são fundamentalmente

\footnotetext{
${ }^{73}$ LEFORT, Le temps présent, p. 255.

${ }^{74}$ LEFORT, As formas da bistória, p. 189.

${ }^{75}$ LEFORT, As formas da bistória, p. 189.

${ }^{76}$ LEFORT, As formas da bistória, p. 189. Grifos nossos.

${ }^{77}$ LEFORT, As formas da bistória, p. 205.

${ }^{78}$ LEFORT, As formas da história, p. 204.
} 
interrogativas, possuem a forma de enigmas produtivos e desbravam, fundando diferentes procedimentos críticos, novos campos discursivos que nos permitem desfazer falsas certezas e lançar nova luz sobre nossos próprios problemas.

Podemos enfim começar a entender por que, inquietos com os problemas da época em que vivemos, debruçamo-nos sobre textos dos séculos XV ou XIX: se ao lermos estes autores aceitamos correr o risco "de ver em seu realismo o advento de certas questões mais do que uma tese" "79, se nos abrimos a encontrar em suas obras "a indicação de um percurso a seguir obrigatoriamente por todo aquele que começa a se interrogar sobre a política mais do que a revelação do que é" 80 , então "somos levados a restituir a Maquiavel e a Marx um igual poder de enfrentarmos nossos próprios problemas" ".1. Se compreendemos que cabe à filosofia política, nos campos do saber e da ação, antes revelar do que esconjurar a incertez̧a e a indeterminação:

Não é um paradoxo sustentar que é tomando a medida desta indeterminação que nos comunicamos com o pensamento deles e, sob o seu efeito, interrogamos nosso tempo. Seus erros não aparecem mais como erros, nem suas contradições como contradições se chegássemos a ler na sua obra a indicação de uma problemática da realidade. ${ }^{82}$

Daí por que, para Lefort, uma obra de pensamento transpassa suas próprias fronteiras espaço-temporais para adquirir "um alcance universal" ${ }^{\prime 3}$, tornando-se capaz de desbravar "uma via de acesso à realidade" 84 : não porque suas proposições possam se alçar ao estatuto de verdades universais, mas porque os problemas com os quais se defronta, as contradições nas quais se enreda, as aporias nas quais desemboca e mesmo os erros que comete constituem aprendizados fundamentais a quem tem por tarefa desmantelar as falsas verdades de seu próprio tempo. Daí, e assim encerramos as investigações com as quais abrimos este texto, o motivo maior da atração por um enigma.

\section{Referências bibliográficas}

CHAUI, M. "O pensamento da obra de pensamento". Resenha do livro de Claude Lefort Le Travail de l'auvre, Machiavel (Paris, Gallimard, 1972). Documento datilografado e não publicado. Departamento de Ciências Sociais - Cadeira de Ciência Política, 1974.

FONTANA, B. Hegemony and power. On the relation between Gramsci and Machiavelli. Minnesota: Minnesota University Press, 1993.

GRAMSCI, A. Notas sobre Maquiavelo, sobre la politica y sobre el Estado moderno. Madrid: Ediciones Nueva Visión, 1980.

\footnotetext{
${ }^{79}$ LEFORT, As formas da história, p. 198.

${ }^{80}$ LEFORT, As formas da história, p. 198.

${ }^{81}$ LEFORT, As formas da história, p. 199.

${ }^{82}$ LEFORT, As formas da bistória, p. 208.

${ }^{83}$ LEFORT, As formas da história, p. 183.

${ }^{84}$ LEFORT, As formas da história, p. 186.
} 
GUIMARÃES, J. "A Revolução democrática e o momento Lefortiano da democracia brasileira". In: Cadernos de Ética e Filosofia Politica, 1 (32), pp. 123-139, 2018. https://doi.org/10.11606/issn.1517-0128.v1i32p123-139

LEFORT, C. Le Travail de l'auvre, Machiavel. Paris: Gallimard, 1972.

. "Bitran, a questão do olho". Tradução de Renato Janine Ribeiro. In: Revista

Discurso, v. 7, n. 7 (1976) pp. 23-50. Disponível em: http://www.revistas.usp.br/discurso/issue/view/3136.

. Écrire - à l'épreuve du politique. Paris: Calmann-Lévy, 1992.

Le temps présent. Paris: Belin, 2007.

- As formas da bistória. Tradução: Luiz Roberto Salinas Fortes e Marilena de Souza

Chauí. São Paulo: Brasiliense, 1979.

. Les formes de l'bistoire. Paris: Éditions Gallimard, 1978.

LELLOUCHE, S. "L'invention du politique. Rencontre avec Claude Lefort". Entrevista concedida à revista Sciences Humaines em 1999. Disponível em: https://www.scienceshumaines.com/l-invention-du-politique-rencontre-avec-claudelefort_fr_10814.html.

MAGALHÃES, J.B. “Lefort diz que mercado não garante sozinho justiça social”. Entrevista concedida por Lefort ao jornal Folha de São Paulo, publicada em 19/04/1992. Disponível em: http://almanaque.folha.uol.com.br/entrevista_filosofia_lefort.htm.

MARX, K.; ENGELS, F. A ideologia alemã. Tradução: Luis Claudio de Castro e Costa. São Paulo: Martins Fontes, 1998.

POLTIER, H. Claude Lefort: la découverte du politique. Éditions Michalon: Paris, 1997.

PLOT, M. (org.) Claude Lefort: thinker of the Political. Nova Iorque: Palgrave, 2013. 